\title{
THE OH COMPONENTS IN GARNETS FROM DIFFERENT GEOLOGICAL ENVIRONMENTS: P-T AND BULK COMPOSITION CONSTRAINTS
}

\author{
Danielle Piuzana $^{1}$, Cristiane Castañeda ${ }^{2}$, Sigrid Griet Eeckhout ${ }^{3}$, Eddy De Grave ${ }^{4}$
}

\begin{abstract}
Metamorphic garnet from the Anápolis-Itauçu Complex (AIC), central Brazil, were investigated by electron microprobe analyses and Mössbauer spectroscopy, in order to contribute on their geological history. The data were further extended by magmatic samples from complex and simple pegmatites, as reported by Eeckhout et al. (2002). Three clear chemical tendencies within garnets from AIC rocks were revealed. From Mössbauer spectroscopy data it is obvious that ferrous iron is present at dodecahedral site. Very small amounts of ferric iron at octahedral site of garnet structure are additionally present in garnets from sample of ultra-high temperature (UHT) granulites from AIC, implying slightly oxidizing conditions during this metamorphicevent. In addition, a higher degree of structural disorder has been discerned in these samples.
\end{abstract}

Keywords

Garnet, petrogenetic indicator, hydroxyl, Mössbauer spectroscopy

\section{INTRODUCTION}

Garnets are important as petrogenetic indicators in igneous and metamorphic rocks, which crystallize at different pressure, temperature and bulk composition conditions. These minerals can be used to obtain precise information about multiple growth stages during a tectonic evolution of a terrain, during prograde as well as retrograde metamorphism (Burton et al. 1995; Harrison and Wood 1980; Mezger et al. 1988; 1991; Rollinson 2003).

The chemical composition of the garnet group minerals (cubic space group $I a 3 d$ and $Z=8$ ) are solid solutions between two or more end members, with the general formula $\mathrm{X}_{3}{ }^{[8]} \mathrm{Y}_{2}{ }^{[6]}\left[\mathrm{SiO}_{4}\right]_{3}$, where $\mathrm{X}$ may be $\mathrm{Mg}^{2+}$, $\mathrm{Fe}^{2+}, \mathrm{Mn}^{2+}$ or $\mathrm{Ca}^{2+}$ and $\mathrm{Y}$ is $\mathrm{Al}^{3+}, \mathrm{Fe}^{3+}, \mathrm{Ti}^{4+}, \mathrm{Cr}^{3+}$ or $\mathrm{V}^{3+}$. They are commonly divided into two series, known as the 'pyralspite' (pyrope-almandine-spessartine) series $\left(\mathrm{Y}=\mathrm{Al}^{3+}\right.$ and $\mathrm{X}=\mathrm{Mg}^{2+}, \mathrm{Fe}^{2+}, \mathrm{Mn}^{2+}$ respectively) and the 'ugrandite' (uvarovite-grossular-andradite) series (X $=\mathrm{Ca}^{2+}$ and $\mathrm{Y}=\mathrm{Cr}^{3+}, \mathrm{Al}^{3+}, \mathrm{Fe}^{3+}$ respectively) (Deer et al. 1982). The structure (e.g., Novak and Gibbs 1971) is described as a three-dimensional framework consisting of corner-sharing $\mathrm{SiO}_{4}$ tetrahedra and $\mathrm{YO}_{6}$ octahedra with $\mathrm{X}$-site cations occupying the large dodecahedral cavities.

Mössbauer spectroscopy applied in Fe-bearing garnets indicates the quantification of ferric iron present in nominally $\mathrm{Fe}^{3+}$-free aluminosilicate garnets. It is a useful technique to assess the oxygen fugacity conditions prevailing during crystallization or during later transformations (Dyar et al. 1998; Eeckhout et al. 2002), and depth formation (Canil and O'Neill 1996; Luth et al. 1990; Woodland and Koch 2003). Furthermore, this spectroscopy reveals the site occupancy of the iron ions. Doublets have been assigned to $\mathrm{Fe}^{3+}$ in octahedral $\mathrm{Y}$ and tetrahedral $\mathrm{Z}$ sites, $\mathrm{Fe}^{2+}$ in dodecahedral $\mathrm{X}$ sites and octahedral $\mathrm{Y}$ sites, and $\mathrm{Fe}^{2+}(\mathrm{X})$ $\rightarrow \mathrm{Fe}^{3+}(\mathrm{Z})$ electron delocalization (e.g., Amthauer et al. 1976; Armbruster and Geiger 1993; Schwartz et al. 1980; Woodland and Ross II 1994).

The present work reports the results of a systematic study of Brazilian garnets from different geological environments using electron microprobe analyses (EMPA), and Mössbauer spectroscopy (MS). The main objective of this work is to extend the earlier results in magmatic garnets (Eeckhout et al. 2002) to more compositions and geological environments, more precisely from garnets of metamorphic rocks of the lowermost continental crust. The different behaviors observed in MS spectra are discussed in order to place further on constraints on $\underline{\mathrm{P}}-\underline{\mathrm{T}}$ and bulk composition conditions, to contribute on the elucidation evolution of the rocks, and, consequently, of the terrains in which they were formed.

\section{SAMPLING AND GEOLOGICAL SETTING}

Four natural garnet samples, which are representative for high-grade metamorphic rocks, were carefully selected from the Anápolis-Itauçu Complex (AIC), located in the central-southern part of the Brasília Belt, central Brazil (Fig. 1). Rocks of the Anápolis-Itauçu Complex include felsic hypersthene-bearing granulite, sillimanite-garnet gneiss, quartzite and carbonate-rich rocks, as well as granulitic mafic-ultramafic intrusions and a large number of granite intrusions, some of which have also been metamorphosed under granulite facies conditions. Almandine-pyrope garnet crystals were selected from ultra-high temperature granulites (ANA 279), granulitized granites (ANA 1, ANA 239) and paragranulites (ANA 259). Petrographically,

1 - Instituto de Humanidades, UFVJM, danielle.piuzana@ufvjm.edu.br

2 - Centro de Pesquisa Manuel Teixeira da Costa/IGC/UFMG, Brasil, ccastaneda@igc.ufmg.br

3 - European Synchrotron Radiation Facility, Grenoble, France

4 - Department of Subatomic and Radiation Physics, Ghent University, Belgium 
paragranulite ANA 259 corresponds to a gray, medium grained, strongly foliated garnet gneiss. The rock is made of quartz, plagioclase, K-feldspar, garnet, sillimanite, and biotite and its mineralogical composition and association with calc-silicate rocks and quartzite suggests derivation from a pelite or greywacke. The ultra-high temperature (UHT) granulite shows a granoblastic texture and consists of quartz, plagioclase, biotite, orthopyroxene, cordierite, garnet, spinel, plagioclase, biotite, sapphirine and rutile. Moraes et al. (2002) suggested that the mineral assemblages of ANA 279 , which show sapphirine and quartz in equilibrium, are indicative of ultra-high temperature metamorphism, with temperatures up to $1150^{\circ} \mathrm{C}$ and pressures above 10 kbar. The associated granites (ANA 1, ANA 239) are gray, medium grained, foliated granites with locally preserved porphyritic texture. They are made of quartz, plagioclase, K-feldspar (orthoclase), garnet, biotite and sillimanite. Zircon and monazite are abundant accessories. Besides the distinct primary mineralogy of ANA 279 compared with other granulites from AIC, $\mathrm{U}-\mathrm{Pb}$ SHRIMP data obtained in metamorphic zircon dates the high-grade metamorphism at ca. 650-640 Ma (Piuzana et al. 2003). Igneous crystallization ages obtained in zircon grains of orthogranulite and granites vary between 760 and $650 \mathrm{Ma}$. Zircon cores from paragranulites and granites give $\mathrm{U}-\mathrm{Pb}$ ages between 2.0 and $0.8 \mathrm{Ga}$. The $\varepsilon_{\mathrm{Nd}}(T)$ values of the granulitic rocks are negative and the SHRIMP U-Pb ages of the zircon cores indicate that the sedimentary granulite protoliths were deposited after $800 \mathrm{Ma}$ ago (Piuzana et al. 2003).
The Sm-Nd garnet-whole rock isochron in sample ANA 1 dates the metamorphic event at ca. $630 \mathrm{Ma}$ (Fischel et al. 1998), indicating that metamorphic garnet growth occurred ca. $20 \mathrm{Ma}$ after metamorphic zircon growth. All garnet samples studied are transparent, have vitreous luster and possess little or no inclusions.

Three Brazilian garnet samples from Eeckhout et al. (2002) were further included for representing the magmatic environment. They belong to the Northeastern and Eastern gemological provinces, both in mobile belts that resulted from the Pan African - Brasiliano Cycle (850 - $550 \mathrm{Ma})$. Orange spessartine, Ge03, was collected from the pockets of the Alto Mirador pegmatite, situated in the lithium-rich Borborema subprovince of the Northeastern province. This pegmatitic body is hosted by quartzites of the Equador Formation, which is attributed to the Serido Thrust-Fold Belt (Pinto and Pedrosa-Soares 2001). In the Eastern gemological province (NE of Minas Gerais State, Brazil) different pegmatitic districts are distinguished, e.g., the Conselheiro Pena district and the São José da Safira district, representing distinct episodes of granitogenesis within the Neoproterozoic Araçuaí Thrust-Fold Belt, viz., at 625-500 Ma and 530-520 Ma, respectively (Morteani et al. 2000; Pedrosa-Soares and Wiedemann-Leonardos 2000; Pedrosa-Soares et al. 2001; Pinto and Pedrosa-Soares 2001). Spessartinealmandine crystals were collected from the pockets of the simple, zoned Escondido pegmatite (Gesc), which belongs to the Conselheiro Pena district, and from

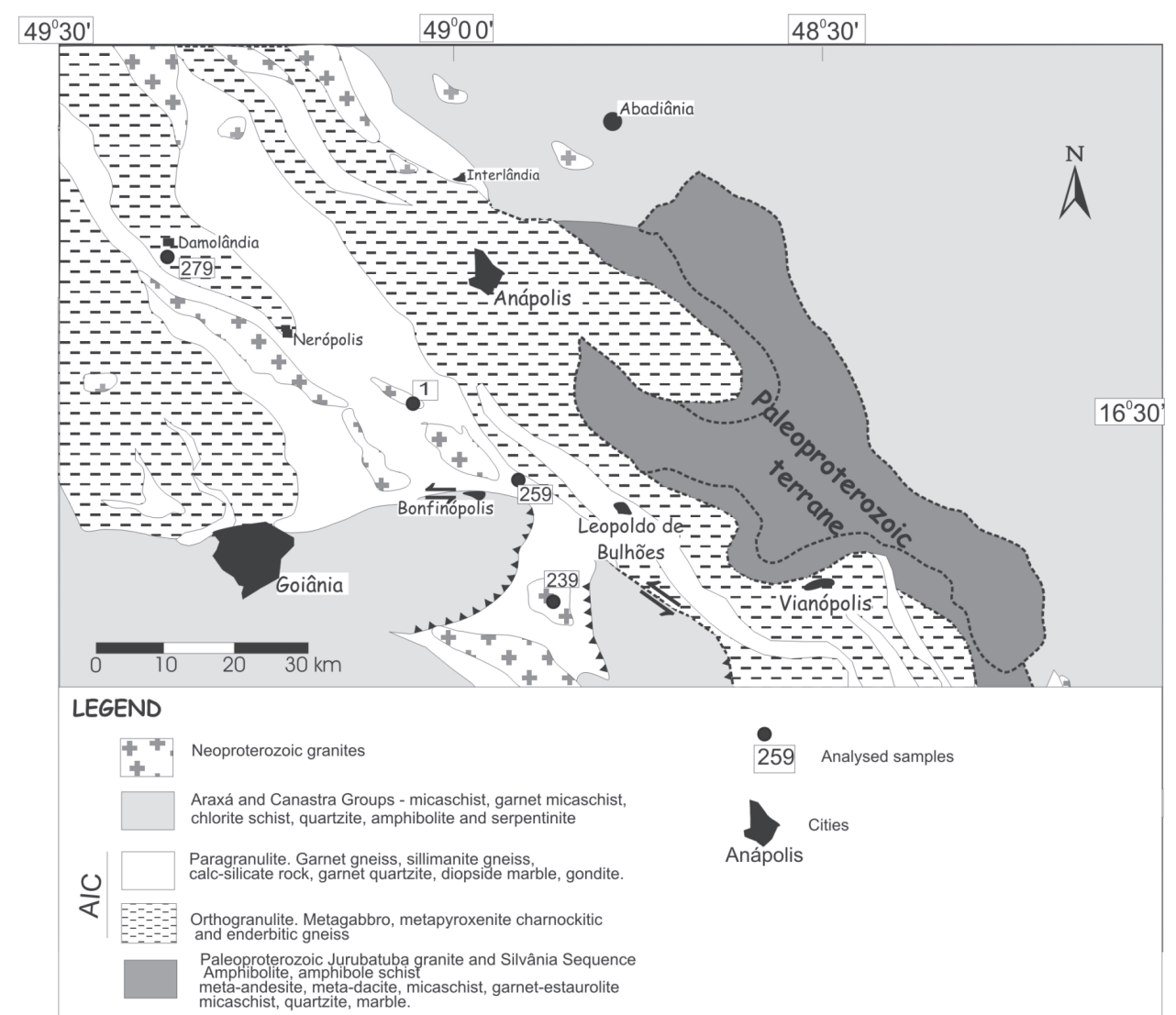

Figure 1: Geological sketch of AIC, Brasilia Belt, Central Brazil (modified from Lacerda Filho \& Oliveira 1995) 
the substitution bodies of the simple Poaiá pegmatite (Gpr), belonging the São José da Safira district. In addition, grossular samples were collected from the Barra do Cuieté pegmatite, Governador Valadares district, Eastern gemological province. For more detailed information the authors refer to Eeckhout et al. (2002).

\section{ANALYTICAL TECHNIQUES}

The metamorphic garnet samples were separated from the host rock by crushing the rock to $\mathrm{cm}$-sized fragments using a jaw crusher. The fragments were then ground, in small batches, in a tungsten carbide disk mill. Heavy mineral concentrates were obtained using a DENSITEST ${ }^{\circledR}$ table. The concentrates were then passed through a Frantz isodynamic magnetic separator to obtain the garnet fraction. The garnet crystals were hand-picked from this fraction under a binocular microscope.

Elemental analyses on such selected, metamorphic garnet single crystals were carried out on a Cameca model Camebax 5X-50 electron microprobe (EMPA) under the following operational conditions: $15 \mathrm{kV}$ acceleration potential and $20 \mathrm{nA}$ sample current. The crystals were analyzed using the following standards: albite $(\mathrm{Si})$, olivine $(\mathrm{Fe}, \mathrm{Mg})$, anorthite $(\mathrm{Ca}, \mathrm{Al})$, rodonite (Mn). The chemical data for each crystal are averages of 5-8 analyses taken uniformly over each crystal. The lower limit of detection was $0.01 \mathrm{wt} \%$.

The ${ }^{57} \mathrm{Fe}$ Mössbauer spectra (MS) were recorded at room temperature (RT) using standard transmission equipment. A triangular source motion was applied and counts were stored in 1024 channels. Typically the number of off-resonance counts per channel (background) was $10^{6}$. The source was ${ }^{57} \mathrm{Co}$ embedded in a $\mathrm{Rh}$ matrix with initial activity of $50 \mathrm{mCi}$. The absorbers were prepared by sealing the finely ground mineral species in an iron-free sample holder with a styrofoam-benzene mixture. The thickness was on the average $\sim 5 \mathrm{mg} / \mathrm{cm}^{2}$ of natural Fe. The velocity scale was periodically calibrated against $\alpha$-Fe foil. The velocity increment per channel was $\sim 0.016 \mathrm{~mm} / \mathrm{s}$. All center-shift values quoted hereafter are relative to $\alpha-\mathrm{Fe}$. The MS were fit with symmetrical Lorentzian doublets (i.e., equal widths and line intensities for the two partner lines of a given doublet). As a general rule, no additional restrictions on the parameter values to be adjusted were imposed. However, since for the considerably broadened ferric doublet component of the metamorphic garnet samples physically unrealistic values were obtained, its center-shift value was kept fixed at $0.36 \mathrm{~mm} / \mathrm{s}$.

\section{RESULTS AND DISCUSSION Crystal chemistry}

The mean values of electron microprobe analyses from metamorphic samples were are summarized in table 1. All metamorphic samples belong to the almandine-pyrope series. End-member calculations indicate variations in the $\mathrm{Fe}$ and $\mathrm{Mg}$ contents and, to a lesser extent, in the $\mathrm{Ca}$ and $\mathrm{Mn}$ content. Garnets from granulitized granites (ANA 1 and 239) present the largest amount of $\mathrm{Fe}(\mathrm{mol} \%)$, alm ${ }_{69-66} \mathrm{py}_{20-26}$ gro $_{6-9} \mathrm{sp}_{2-3}$, followed by garnets from paragranulites (ANA 259), alm $_{62-52} \mathrm{py}_{42-32}$ gro $_{4-6} \mathrm{sp}_{1-2}$ and finally UHT granulites (ANA 279), alm ${ }_{63} \mathrm{py}_{23} \mathrm{gro}_{13} \mathrm{sp}_{1}$. According to the $\mathrm{mol} \%$ of almandine and pyrope, two groups of garnets can be distinguished. Garnets from paragranulites show values of $<60 \mathrm{~mol} \%$ of almandine and $>30 \mathrm{~mol} \%$ of pyrope, whereas garnets from granulitized granites and UHT granulites show values of $>60$ and between 20 and 25 , respectively. In the same way, the- $\mathrm{Mg} /(\mathrm{Mg}+\mathrm{Fe})$ ratio or the $\mathrm{Ca} /(\mathrm{Ca}+\mathrm{Mg})$ ratio can be used. The garnet samples taken from ultra-high temperature granulites (ANA 279) show values between $0.15-0.27 \mathrm{Mg} /(\mathrm{Mg}+\mathrm{Fe})$ and 0.35 $\mathrm{Ca} /($ Creserved up to higher temperatures (Mezger et al. 1988). In addition, this pattern can also be observed in the chemical profiles of single crystals (Table 1). The analyzed single crystals reveal a systematic relationship between $\mathrm{Fe}, \mathrm{Mg}$ and $\mathrm{Ca}$ contents. In all of them, the iron is slightly higher in rim than in core of the crystals. $\mathrm{Mg}$ and $\mathrm{Ca}$ contents in UHT garnets present a negative correlation with $\mathrm{Fe}$, showing gradual decrease of these two elements towards the crystal rim. On the other hand, in granulitized granites the trend of $\mathrm{Ca}$ and $\mathrm{Mg}$ remains constant throughout the crystal.

In summary, three chemical tendencies have been observed within the metamorphic context of the Anápolis-Itauçu Complex: (i) UHT granulites (ANA 279), whose garnets present larger concentrations in aluminum and calcium (core); (ii) concomitant partial melt and high grade metamorphism, marked by homogeneous distribution of $\mathrm{Fe}, \mathrm{Mg}$ and $\mathrm{Ca}$ ions through the crystal of samples ANA 1 and ANA 239, and (iii) the granulitization sensu strictu characterized by paragranulitic slices (ANA 259) whose garnets show inverse geochemical features.

In contrast with the garnets from the metamorphic rocks, which belong to the almandine-pyrope series, the pegmatitic garnet samples studied belong to the spessartine-almandine series. Within the magmatic environment, the garnet samples show a remarkable difference in composition, especially concerning $\mathrm{Fe}$, $\mathrm{Ca}$ and $\mathrm{Mn}$ contents. Two groups of garnets have be distinguished according to the $\mathrm{Mg} /(\mathrm{Mg}+\mathrm{Fe})$ ratio or, similarly, according to the $\mathrm{Ca} /(\mathrm{Ca}+\mathrm{Mg})$ ratio (Eeckhout et al. 2002). The garnet samples taken from the pockets show values between $0.34-0.40 \mathrm{Mg} /(\mathrm{Mg}+\mathrm{Fe})$ and 0.15 $0.36 \mathrm{Ca} /(\mathrm{Ca}+\mathrm{Mg})$, whereas the garnets from substitution bodies, representing a primary crystallization, have values around 0.00 and 0.95 , respectively. The Escondido and the Poaiá pegmatite, which are simple pegmatites, are richer in iron and poorer in calcium as compared to the complex Alto Mirador pegmatite, which has a higher evolutional degree. 
Table 1: Average composition (wt\%) of the metamorphic garnet samples.

\begin{tabular}{|c|c|c|c|c|c|c|c|c|}
\hline & ANA 259 rim & ANA 259 core & ANA 1 rim & ANA 1core & Ana 239 rim & ANA 239 core & ANA 279 rim & ANA 279 core \\
\hline & \multicolumn{2}{|c|}{ Paragranulite } & \multicolumn{4}{|c|}{ Granulitized granites } & \multicolumn{2}{|c|}{ UHT granulite } \\
\hline $\mathrm{SiO}_{2}$ & 37.29 & 37.23 & 36.99 & 36.98 & 36.41 & 36.52 & 38.65 & 39.61 \\
\hline $\mathrm{Al}_{2} \mathrm{O}_{3}$ & 22.09 & 22.03 & 21.77 & 21.92 & 21.36 & 21.45 & 22.84 & 22.97 \\
\hline MgO & 8.72 & 8.52 & 6.50 & 6.70 & 5.31 & 5.42 & 2.41 & 4.08 \\
\hline $\mathrm{CaO}$ & 1.34 & 1.95 & 2.53 & 2.45 & 3.23 & 3.09 & 1.78 & 3.26 \\
\hline MnO & 0.86 & 0.89 & 1.02 & 1.03 & 1.18 & 1.01 & 0.72 & 0.28 \\
\hline $\mathrm{FeO}$ & 29.26 & 29.13 & 31.64 & 31.05 & 32.05 & 32.15 & 23.71 & 20.05 \\
\hline Total & 99.55 & 99.75 & 100.45 & 100.13 & 99.53 & 99.64 & 90.10 & 90.24 \\
\hline \multicolumn{9}{|c|}{ Numbers of ions on the basis of $12 O$} \\
\hline $\mathbf{S i}$ & 2.92 & 2.91 & 2.92 & 2.92 & 2.92 & 2.92 & 3.23 & 3.25 \\
\hline $\mathbf{A l}^{I^{I V}}$ & 0.08 & 0.09 & 0.08 & 0.08 & 0.08 & 0.08 & 0.00 & 0.00 \\
\hline $\mathrm{Al}^{\mathrm{VI}}$ & 1.96 & 1.95 & 1.94 & 1.95 & 1.93 & 1.94 & 2.25 & 2.22 \\
\hline $\mathrm{Fe}^{2+}$ & 1.92 & 1.91 & 2.09 & 2.05 & 2.15 & 2.15 & 1.66 & 1.38 \\
\hline Mg & 1.02 & 0.99 & 0.76 & 0.79 & 0.63 & 0.65 & 0.30 & 0.50 \\
\hline Mn & 0.06 & 0.06 & 0.07 & 0.07 & 0.08 & 0.07 & 0.05 & 0.02 \\
\hline $\mathrm{Ca}$ & 0.11 & 0.16 & 0.21 & 0.21 & 0.28 & 0.26 & 0.16 & 0.29 \\
\hline $\mathrm{Ca} / \mathrm{Ca}+\mathrm{Mg}$ & 0.10 & 0.14 & 0.22 & 0.21 & 0.30 & 0.29 & 0.35 & 0.36 \\
\hline $\mathrm{Mg} / \mathrm{Mg}+\mathrm{Fe}$ & 0.35 & 0.34 & 0.27 & 0.28 & 0.23 & 0.23 & 0.15 & 0.27 \\
\hline
\end{tabular}

\section{MÖSSBAUER SPECTROSCOPY}

The hyperfine-interaction characteristics as reflected in the Mössbauer spectra (MS) at RT for the magmatic and metamorphic garnets were found to be similar. They are characterized by one sharp, slightly asymmetric ferrous doublet and, in addition, a weak inner doublet centered around $0.4 \mathrm{~mm} / \mathrm{s}$ might be present (Fig. 4). The best-fit parameters obtained are listed in Table 2. They show $\mathrm{Fe}^{2+}$ at the dodecahedral $\mathrm{X}$ site and $\mathrm{Fe}^{3+}$ at the octahedral Y site (e.g., Amthauer et al. 1976; Armbruster and Geiger 1993; Schwartz et al. 1980; Woodland and Ross II 1994). It is important to note at this point that considering the small amount of $\mathrm{Fe}$ in orange spessartine from the Alto Mirador pegmatite, Ge03, and the identical overall behavior of the garnets from this pegmatite, the hyperfine parameters for another, representative spessartine sample, Gae 01 , is mentioned in Table 2 (Eeckhout et al. 2002). For metamorphic garnet, the ferric doublet is considerably broadened with line width values of at least twice the values $(\sim 0.29 \mathrm{~mm} / \mathrm{s}$, full width at half maximum) obtained in magmatic garnet. Qualitatively, this line broadening can be attributed to local compositional variations in the cationic configurations in the neighboring coordination shells and reflects the chemical and charge disorder in the surrounding edge-sharing dodecahedra. The dodecahedral disorder does not affect the full width at half maximum of the dodecahedral ferrous iron (Table 2). In the garnet crystal structure, each dodecahedron shares edges with other dodecahedra, octahedra and tetrahedra, whereas the octahedron shares edges with dodecahedra and corners with tetrahedra. Furthermore, the distance between two dodecahedra is larger than between a dodecahedron and an octahedron, hence less affecting the full width at half maximum. The octahedral disorder as observed from the broad full width at half maximum of the ferric iron in UHT granulites (Fig 2d) might be ascribed to the presence of $\mathrm{C}-\mathrm{H}$ substitutions at the corner-sharing tetrahedral site. In addition, other

Table 2: ${ }^{57} \mathrm{Fe}$ Mössbauer hyperfine parameters of metamorphic (Ana 1, Ana 239, Ana 259 and Ana 279) and magmatic (Gae01, Gesc, Gpr) garnets at room temperature (RT): Center shift $\delta(\mathrm{mm} / \mathrm{s}$, relative to $\alpha-F e)$, quadrupole splitting $\Delta E_{Q}(\mathrm{~mm} / \mathrm{s})$, full width at half maximum $\Gamma(\mathrm{mm} / \mathrm{s})$ and relative area $R A$.

\begin{tabular}{lllllllll}
\hline \multicolumn{1}{c}{ Sample } & $\delta_{1}(\mathrm{~mm} / \mathrm{s})$ & $\delta_{2}(\mathrm{~mm} / \mathrm{s})$ & $\Delta E_{\mathrm{Q}, 1}(\mathrm{~mm} / \mathrm{s})$ & $\Delta E_{\mathrm{Q}, 2}(\mathrm{~mm} / \mathrm{s})$ & $\Gamma_{1}(\mathrm{~mm} / \mathrm{s})$ & $\Gamma_{2}(\mathrm{~mm} / \mathrm{s})$ & $\mathrm{RA}_{1}$ & $\mathrm{RA}_{2}$ \\
\hline ANA 1 & $1.277(5)$ & & $3.538(10)$ & & $0.27(1)$ & & 100 & \\
ANA 239 & $1.278(5)$ & $0.360(5)$ & $3.535(10)$ & $0.216(10)$ & $0.28(1)$ & $0.77(1)$ & $94(1)$ & $6(1)$ \\
ANA 259 & $1.278(5)$ & & $3.543(10)$ & & $0.26(1)$ & & 100 & \\
ANA 279 & $1.277(5)$ & $0.360(5)$ & $3.548(10)$ & $0.133(10)$ & $0.28(1)$ & $0.84(1)$ & $96(1)$ & $4(1)$ \\
Gae01 & $1.276(5)$ & $0.337(5)$ & $3.548(10)$ & $0.313(10)$ & $0.28(1)$ & $0.29(1)$ & $86(1)$ & $14(1)$ \\
Gesc & $1.280(5)$ & & $3.547(10)$ & & $0.27(1)$ & & 100 & \\
Gpr & $1.281(5)$ & & $3.547(10)$ & & $0.29(1)$ & & 100 & \\
\hline
\end{tabular}


mechanisms might play a role, such as the presence of $\mathrm{CO}_{2}$ and $\mathrm{NO}_{2}$.

In general, the evaluation of site occupancies from the relative spectral areas of the respective subspectra resolved from a MS is a matter of dispute. It is commonly assumed that the recoil-free fractions $\underline{f}$ of the Fe species in a given mineral sample are the same at each non-equivalent site, regardless of the charge of the iron atom, however, a correction of $\sim 5 \%$ in favor of the $\mathrm{Fe}^{2+}$ content is estimated and thought to be reasonable
(De Grave and Van Alboom 1991; Eeckhout and De Grave 2003). Consequently, it was found that within the metamorphic environment, about $5 \%$ of the total Fe content of the garnets from the UHT granulites is ferric, whereas the garnets from granulitized granites and from paragranulites only possess ferrous iron (Fig 2 a,b,c). Within the magmatic environment, the $\mathrm{Fe}^{2+} /$ $\mathrm{Fe}^{3+}$ ratio is comparable for all samples of the complex Alto Mirador pegmatite, i.e., $\sim 10 \%$, implying a same geological history, namely similar oxygen fugacities
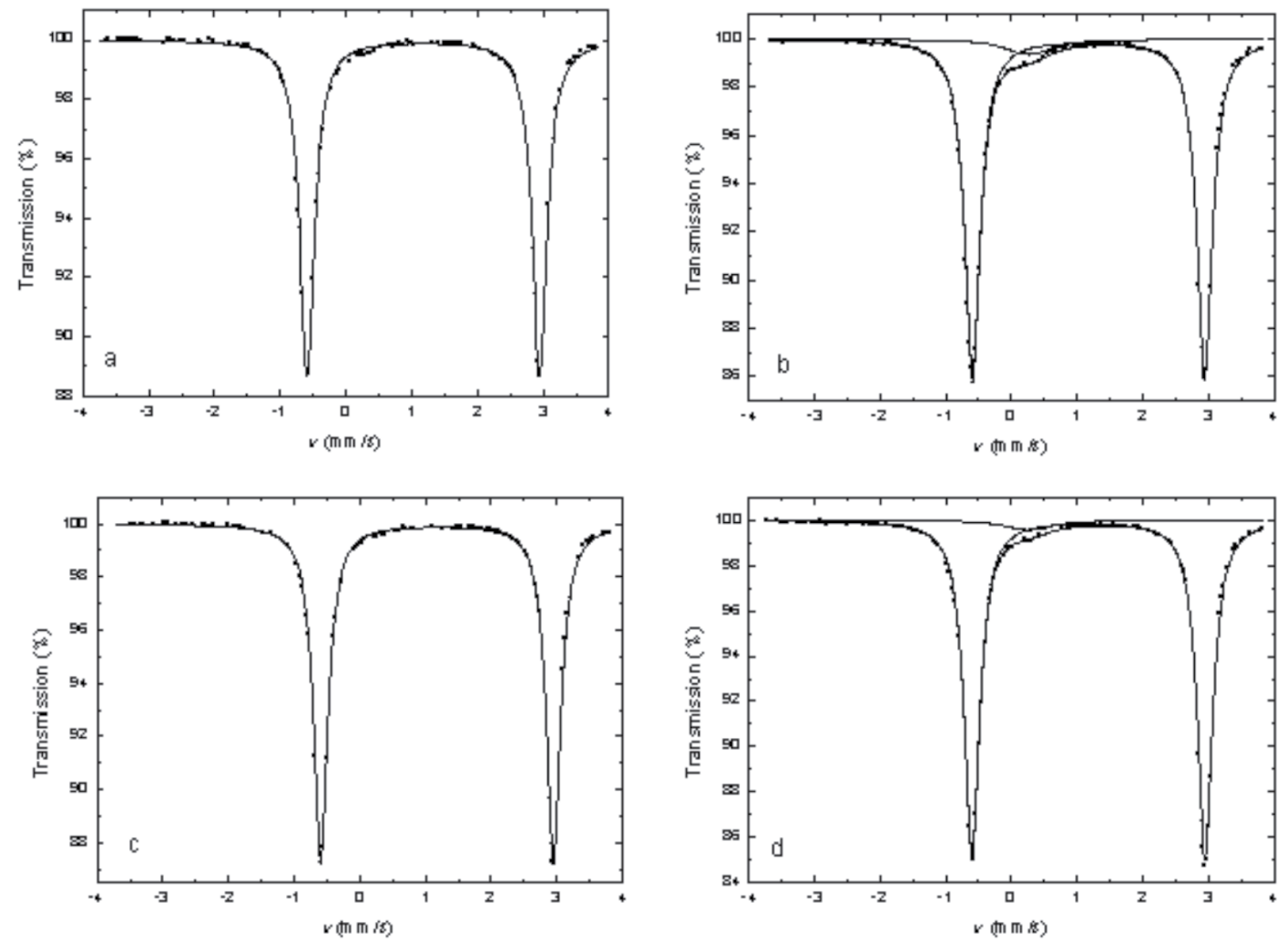

Figure 2: Experimental (dots) and calculated (solid lines) Mössbauer spectra at room temperature of (a) ANA 1, (b) ANA 239, (c) ANA 259, (d) ANA 279.

were acting at the moment of garnet formation. In the simple pegmatites, however, almost no ferric iron has been detected (Eeckhout et al. 2002). For magmatic garnets, the very small amount of ferric iron at the octahedral sites can be related to the presence of late, aqueous fluids, hence causing somewhat oxidizing environments. For metamorphic garnets, the extremely small amount of ferric iron might be due to very slightly oxidizing conditions during the UHT metamorphic event.

\section{ACKNOWLEDGEMENTS}

The authors are indebted to the Brazilian researchfounding agencies CAPES (Cristiane Castañeda) and Conselho Nacional de Pesquisa (CNPq) (Danielle Piuzana - Grant 300121/02-4), and Ghent University, Belgium, for the support for the Mössbauer study.

\section{REFERENCES CITED}

AMTHAUER G, Annersten H, Hafner SS (1976) The Mössbauer spectrum of ${ }^{57} \mathrm{Fe}$ in silicate garnets. Zeitschrift für Kristall 143: 14-55

ARMBRUSTER T, Geiger CA (1993) Andradite crystal chemistry, dynamic X-site disorder and structural strain in silicate garnets. Eur J Mineral 5: 59-71

BASSO R, Cimmino F, Messiga B (1984) Crystal chemistry of hydrogarnets from three different microstructural sites of a basaltic metarodingite from the Voltri Massif (Western Liguria, Italy). Neues Jahrb Mineral 148: 246-258

CANIL D, O'Neill HStC (1996) Distribution of ferric iron in some upper-mantle assemblages. J Petrol 37: 609-635

DEER WA, HOWIE RA, ZUSSMAN J (1982) Rock-forming minerals, Vol. 1A, Orthosilicates, Longman, London, pp 696

DE GRAVE E, VAN ALBOOM A (1991) Evaluation of ferrous and ferric Mössbauer fractions. Phys Chem Minerals 18: 337-342

DYAR MD, TAYLOR ME, LUTZ TM, FRANCIS CA, GUIDOTTI CV, WISE M (1998) Inclusive chemical characterization of tourmaline: Mössbauer study of Fe valence and site occupancy. Am Mineral 83: 848-864 
EECKHOUT SG, DE GRAVE E (2003) Evaluation of ferrous and ferric Mössbauer fractions: Part II. Phys Chem Minerals 30: 142-146

FISCHEL, DP, PIMENTEL, MM, FUCK, RA, (1998) Idade do metamorfismo de alto grau no Complexo Anápolis-Itauçu, determinada pelo método Sm-Nd. Rev Bras Geoc 28 (4): 543 544

HARRISON WJ, WOOD BJ (1980) An experimental investigation of the partitioning of REE between garnet and liquid with reference to the role of defect equilibria. Contrib Mineral Petrol 72: $145-155$

LAGER GA, ARMBRUSTER T, ROTELLA FJ, ROSSMAN GR (1989) OH substitution in garnets: X-ray and neutron diffraction, infrared, and geometric-modeling studies. Am Mineral 74 840-851

LACERDA FILHO JV, OLIVEIRA CC (1995) Geologia da região centro-sul de Goiás. Bol Geoc Centro-Oeste, 18(1/2): 3-19

LUTH RW, VIRGO D, BOYD FR, WOOD BJ (1990) Ferric iron in mantle-derived garnets, implications for thermobarometry and for the oxidation state of the mantle. Contrib Mineral Petrol 104: 56-72

MEZGER K, HANSON GN, BOHLEN SR (1988) U-Pb systematics of garnet dating the growth of garnet in the late Archean Pikwitonei granulite domain at Cauchon and Natawahunan Lakes. Contrib Mineral Petrol 101: 136-148

MEZGER K, RAWSLEY CM, BOHLEN SR, HANSON GN (1991) $\mathrm{U}-\mathrm{Pb}$ garnet, sphene, monazite, and rutile: implications for the duration of high-grade metamorphism and cooling histories, Adirondack Mts., New York. J Geol99: 415-418

MORTEANI G, PREINFALK C, HORN AH (2000) Classification and mineralization potential of the pegmatites of the Eastern Brazilian Pegmatite Province. Mineral Deposita 35: 638-655.

NOVAK GA, GIBBS G (1971) The crystal chemistry of the silicate garnets. Am Mineral 56: 791-825

MORAES R, BROWN M, FUCK RA, CAMARGO MA, LIMA TM (2002) Characterization and P-T Evolution of Melt bearing Ultrahigh-temperature Granulites: an example from the Anápolis-Itauçu Complex of the Brasília Fold Belt, Brazil. J Petrol 43:1673-1705

PEDROSA-SOARES AC, WIEDEMANN-LEONARDOS CM (2000) Evolution of the Araçuaí belt and its connection to the Ribeira belt, eastern Brazil, 265-285. In: Cordani UG, Milani EJ, Thomaz A, Campo DA (eds.) Tectonic evolution of South America, Rio de Janeiro: $31^{\text {st }}$ International Geological Congress, August 6-17-2000, $856 \mathrm{p}$

PEDROSA-SOARES AC, PINTO CP, NETTO C, ARAÚJO MC, CASTAÑEDA C, ACHTSCHIN AB, BASÍLIO M (2001) A província gemológica oriental do Brasil. 16-33. In: Castañeda C, Addad JE, Liccardo A (eds.) Gemas de Minas Gerais, Belo Horizonte, SBG-MG, Brazil, $288 \mathrm{p}$

PINTO CP, PEDROSA-SOARES AC (2001) Brazilian gem provinces. Austr Gemmol, 21: 12-16

PIUZANA D, PIMENTEL MM, FUCK RA, ARMSTRONG RA (2003) Neoproterozoic granulite facies metamorphism and coeval granitic magmatism in the Brasília Belt, Central Brazil: regional implications of new SHRIMP U-Pb and $\mathrm{Sm}-\mathrm{Nd}$ data. Precambr Res 125: 245-273

PIUZANA, D; CASTANEDA, C.; PIMENTEL, M.M.; FUCK, R.; SOARES, W. (2005) Química Mineral em granadas de diferentes níveis crustais. Geonomos, 13(1,2): 29-36.

ROLLINSON, H (2003) Metamorphic history suggested by garnet-growth chronologies in the Isua Greenstone Belt, West Greenland. Precambr Res 126: 181-196

SCHWARTZ KB, NOLET DA, BURNS RG (1980) Mössbauer spectroscopy and crystal chemistry of natural Fe-Ti garnets. Am Mineral 65: 142-153

WOODLAND AB, ROSS II CR (1994) A crystallographic and Mössbauer spectroscopic study of $\mathrm{Fe}_{3}^{2+} \mathrm{Al}_{2} \mathrm{Si}_{3} \mathrm{O}_{12}-\mathrm{Fe}_{3}^{2+} \mathrm{Fe}_{2}^{3+}$ $\mathrm{Si}_{3} \mathrm{O}_{12}$, (almandine-"skiagite") and $\mathrm{Ca}_{3} \mathrm{Fe}_{2}^{3+} \mathrm{Si}_{3} \mathrm{O}_{12}-\mathrm{Fe}_{3}^{2+} \mathrm{Fe}_{2}^{3+}$ $\mathrm{Si}_{3} \mathrm{O}_{12}$, (andradite-"skiagite") garnet solid solutions. Phys Chem Minerals 21: 117-132 